\title{
HIGHER EDUCATION INTERNAL ACADEMIC QUALITY AUDIT INFORMATION SYSTEM
}

\author{
Lande Sudianto ${ }^{* 1} \bowtie$, Petrus Simon 2 (iD) \\ ${ }^{*}$ Electrical Engineering, University of Christian Indonesian Paulus, Indonesia \\ ${ }^{2}$ Accounting, University of Christian Indonesian Paulus, Indonesia
}

DOI: https://doi.org/10.29121/granthaalayah.v8.i11.2020.2380

Article Type: Research Article

Article Citation: Lande Sudianto, and Petrus Simon. (2020). HIGHER EDUCATION INTERNAL ACADEMIC QUALITY AUDIT INFORMATION SYSTEM. International Journal of Research -GRANTHAALAYAH, 8(11), 277-286.

https://doi.org/10.29121/granthaa layah.v8.i11.2020.2380

Received Date: 06 November 2020

Accepted Date: 30 November 2020

Keywords:

Higher Education

Database

Information Systems

AMAI

UKI Paulus

SDLC

\section{ABSTRACT}

University of Christian Indonesian Paulus (UKI Paulus) had started the college quality assurance system by setting the standard, policy and quality of documents. However, it is not supported yet by the information system, which make the process of standard socialization, policy and quality document were not effective and causes limited access to anyone who need the information. Moreover, during the implementation of monitoring and evaluation (monev), quality audits is also inefficient and become a barrier for the implementation of the quality assurance system. Therefore, the information system based on data Internal Academic Quality Audit (Audit MutuAkademik Internal/AMAI) was developed using Unified Modeling Language as part of information and communication technology. The assessment of AMAI of UKI Paulus was carried out by the auditors to every departments by seeing the audited form then count the score of each rubric in order to obtain the standard value and perspective. The system of AMAI provides the report of academic quality assessment from each department to the related leader of the implementation unit. The presence of this system had helped the implementation of quality assurance system for university in order to improve the quality of their institution. The development of information system based on data, AMAI, uses the five stages paradigm of the System Development Life Cycle (SDLC): (1) identification of system requirements; (2) analysis and modeling system; (3) making the system; (4) system assessment and improvement; (5) implementation.

\section{INTRODUCTION}

In the last few years, the Higher Education Quality Assurance System (SPM-PT) has become very important in supporting the success and quality of the tertiary institutions to become healthier (better). Since the General Directorate of Higher Education announced a strategic position of quality assurance in the Higher Education Long Term Strategy (HELTS) 2003 - 2004, the coordination of the Academic Directorate quality assurance activities have developed in such a way in each university. To implement SPM-PT, each university needs to be phased in accordance with the readiness of higher education, however, it is better to set the time frame for the implementation.

Implementation of SPM-PT generally starts from educational activities, continues in the field of research then community service, thus covering all academic activities. After being able to implement SPM-PT in the academic field, then it can be developed into a broader field, for example finance, human resources and so on. The final goal of

(C) 2020 The Author(s). This is an open access article distributed under the terms of the Creative Commons Attribution License, which permits unrestricted use, distribution, and reproduction in any medium, provided the original author and source are credited. 
SPMPT is to guarantee and improve the quality of all fields related to higher education management in order to create healthier and better universities.

Higher Education Quality Assurance is a multi-stakeholder concept; wider community, national, worldwide and the General Director of Higher Education as well. Higher education quality assurance systems are carried out on the basis of internal quality assurance, external quality assurance, and licensing of program implementation. Directly or indirectly, the concept of quality assurance is related to the input and output produced from a university, so that the university is able to produce alumni who has quality as the expectations of stakeholders.

University Christian Indonesia Paulus (UKI Paulus) is a university that has been established since 1963. UKI Paulus has a vision "To become one of the leading universities that always rely on the grace of God Almighty, featuring high quality, independent, creative graduates, innovative, full of enthusiasm and able to compete". To obtain this vision, UKI Paulus had used Quality Assurance Agency since 2009. Related to the concept of the quality assurance system that has been stated above, this is a capital of trust that must be built by UKI Paulus. To gain trust in quality, it is necessary to have a good quality assurance system supported by good information technology as well.

Based on the observations, currently the implementation of the quality assurance system at UKI Paulus has been implemented by establishing quality standards and policies. The next stage will be continued with the realization and evaluation of the quality assurance system. At the moment, the problem of the quality assurance system is things done manually, such as procedures and policies that are archived manually, socialization only through meetings so that there is limited access for those who need it. In addition, monitoring and evaluation of lectures are also done manually so that it takes a longer time to get the results. Therefore, it requires information system support that can accommodate all the needs of the quality assurance system.

The rapid development of Information Technology (IT) has led to low cost hardware and software. This development has led to various applications and management models for IT. These various IT developments have made many companies experience a shift from manual to computerized systems so that data storage is efficient, information is up to date, and is fast in presenting information. International measurement standards in an organization called the International Standard Organization (ISO) are not only in manufacturing companies but can be carried out in universities (PT). An educational institution has a control factor, information and documentation that are important and affects the quality of an educational institution.

One of them is academic quality assurance activity at university which is carried out by the internal audit in each unit and department. The audit is based on the standards in order to achieve the predetermined audit objectives. Information in educational institutions is as important as in a company. The information must be protected. One of the information that affects the quality of education is the information contained in the internal audit, where the internal audit at university (PT) is directed to the quality control audit of the study program and each unit. The collection of information that is useful for assessing the quality of departments and units must be carried out through several stages of the audit process that takes a long time if done manually, such as making audit questions, determining clauses, findings that cause process standards or targets not achieved, when improvements from the findings, documenting the findings and correcting the findings as well as documenting and searching for previous audit information takes a long time. To maintain the quality of the study program and unit, as well as the increasingly complex quality assurance in the future, it is necessary to design an information system that can facilitate auditing and provide information with complete documentation related to the existing process and can serve as a media of socialization related to the quality process at the university.

UKI Paulus Internal Academic Quality Audit is a Quality Assurance and Consultation activity that is independent and objective. This activity is designed to: (1) Provide added value and improve the academic operational performance of UKI Paulus; (2) Knowing that the efforts to maintain, improve the quality and academic standards already appropriate and effective; (3) Identifying the scope of professional improvement and development sustainability based on self-evaluation. The problems found in this study include: (1) The conventional process of collecting, compiling data and producing quality audit reports takes a long time; (2) Supporting documents are scattered, including damaged and missing, thus hampering the preparation process which will be used as a supporting attachment in the quality audit and accreditation processes. From the description of the background of this study, it can be concluded that in the process of monitoring and auditing quality of higher education, an information system that provides accurate, fast and precise higher education quality data is needed.

The purpose of this research is the development of appropriate technology in the form of the UKI Paulus Internal Academic Quality Audit Information System Database (AMAI) based on information and communication technology 
Higher Education Internal Academic Quality Audit Information System

which is able to facilitate auditing and provide information with complete documentation related to existing processes and as a media for the socialization of the quality process in Higher Education.

\section{MATERIALS AND METHODS}

Internal Quality Assurance System (SPMI) is a systemic activity of higher education quality assurance in Tertiary Education Institutions by Tertiary Education Institutions, to supervise the implementation of higher education by Tertiary Education Institutions in a sustainable manner. In SPMI, the concept used is the PDCA (Plan, Do, Check, Action) concept in Kaizen. Kaizen comes from Japanese which means "improvement" or "continuous improvement" which involves everyone, including top management, managers and all employees, because kaizen is the responsibility of every individual/person. The PDCA concept in Kaizen is carried out to maintain existing standards and achieve the expected goals. The Plan stage itself is a stage which purpose to formulate or plan a standard assessment. The Do stage, at this stage the SPMI document is made in accordance with the standards that have been formulated. Furthermore, at the Check stage, an evaluation of the related universities is carried out. The last stage is Action. At this stage, focus on the results of the evaluation and start making improvements according to the results of the evaluation obtained.

Internal Academic Quality Audit / AMAI is a quality assurance and consulting activity in the academic field which is regulated by an internal institution belonging to higher education which aims to ensure the results of the audit are in accordance with the predetermined plan. AMAI is also the result of the formulation of standards that exist in SPMI which makes AMAI used as a system at the Check stage to evaluate the operational performance of a university.

The UKI Paulus Quality Assurance Agency (BPM) has the responsibility to develop a quality management system, ensure the implementation of the quality management system, and conduct evaluations, and continuously improve and develop a quality assurance system, both at the university level to study programs and lecturer resources.

The general objective of AMAI is to assist all managers within UKI Paulus in carrying out their duties to: 1) achieve quality objectives both academic and non-academic which have been determined effectively and responsibly in internal quality standards; 2) help managers identify the scope of improvement and develop it on an ongoing basis; and 3) improving the program and planning academic and non-academic activities in UKI Paulus. Monitoring and evaluation activities aim for accountability, while audit activities are intended to determine focus, planned improvement and development efforts. AMAI becomes a systematic and independent inspection activity to determine whether activities to maintain quality and results are in accordance with predetermined plans and have been implemented effectively.

BPM UKI Paulus monitors, evaluates and audits both at the level of study programs, faculty / graduate programs and universities. Monitoring, evaluation and auditing at the study program level includes the Undergraduate and Postgraduate Study Programs. BPM UKI Paulus provides an AMAI instrument that will be used by auditors in monitoring and evaluation. The AMAI UKI Paulus instrument includes 11 (eleven) standards, including: Content Standards, Process Standards, Graduate Competency Standards, Educators and Education Personnel Standards, Facilities and Infrastructure Standards, Management Standards, Financing Standards, Assessment Standards, Research Standards, Community Service Standards and Cooperation Standards. This instance is presented in the excel file format as shown in Figure 1.

Each unit / study program fills in the AMAI Instrument on the basis of the principle of need, honestly and responsibly so that a real quality map is obtained. The quality map will be used for planning development programs and academic / non-academic activities both by the study program itself, faculties and universities so that continuous improvement can be carried out effectively for the achievement of internal quality standards until 2020 
Lande Sudianto, and Petrus Simon

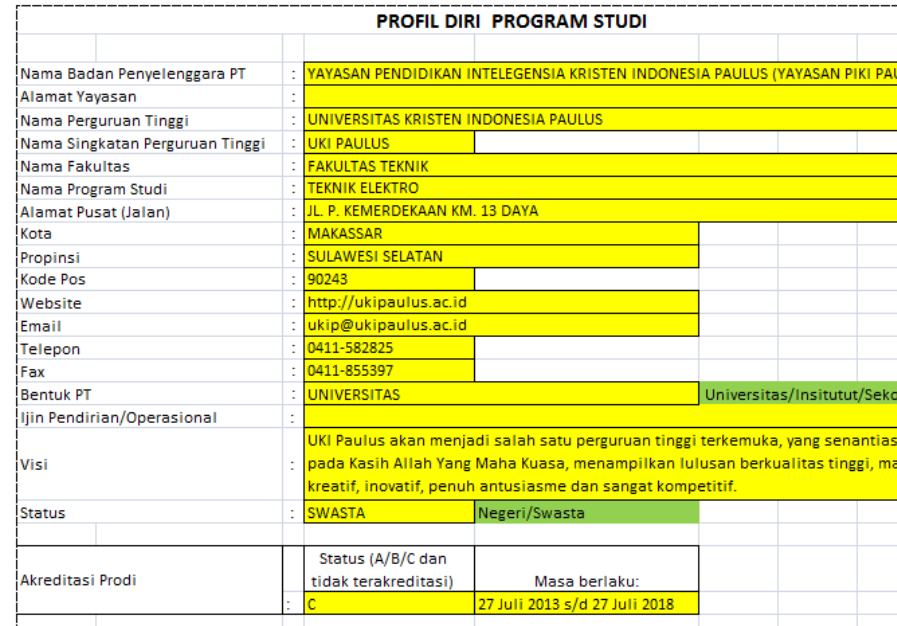

a. Self profile

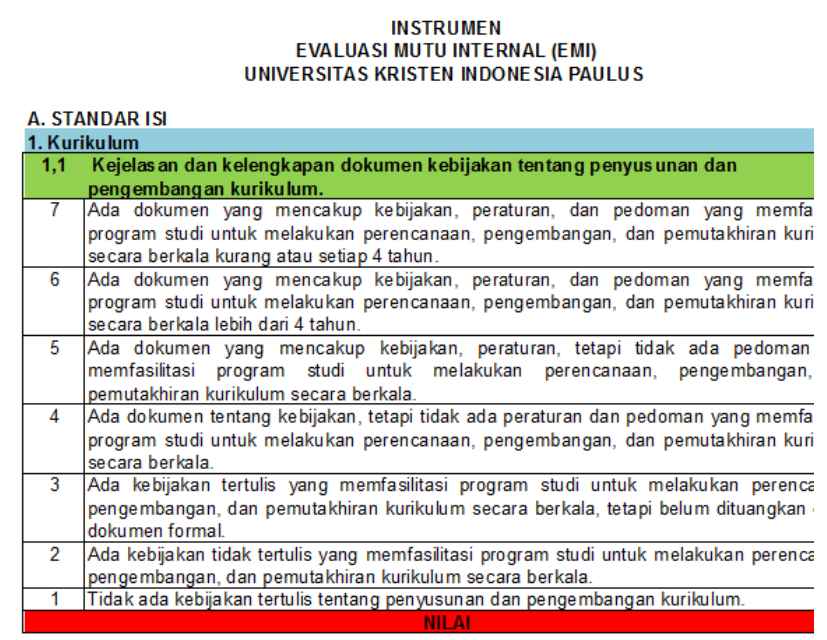

b. Assessment instrument per standard

Figure 1: The UKI Paulus AMAI instrument

The stages of developing a Quality Assurance Management Information System in Higher Education are made using a System Development Life Cycle (SDLC) paradigm approach which consists of 5 stages: (1) identification of system requirements; (2) system analysis and modeling; (3) system creation; (4) system testing and repair; and (5) implementation.

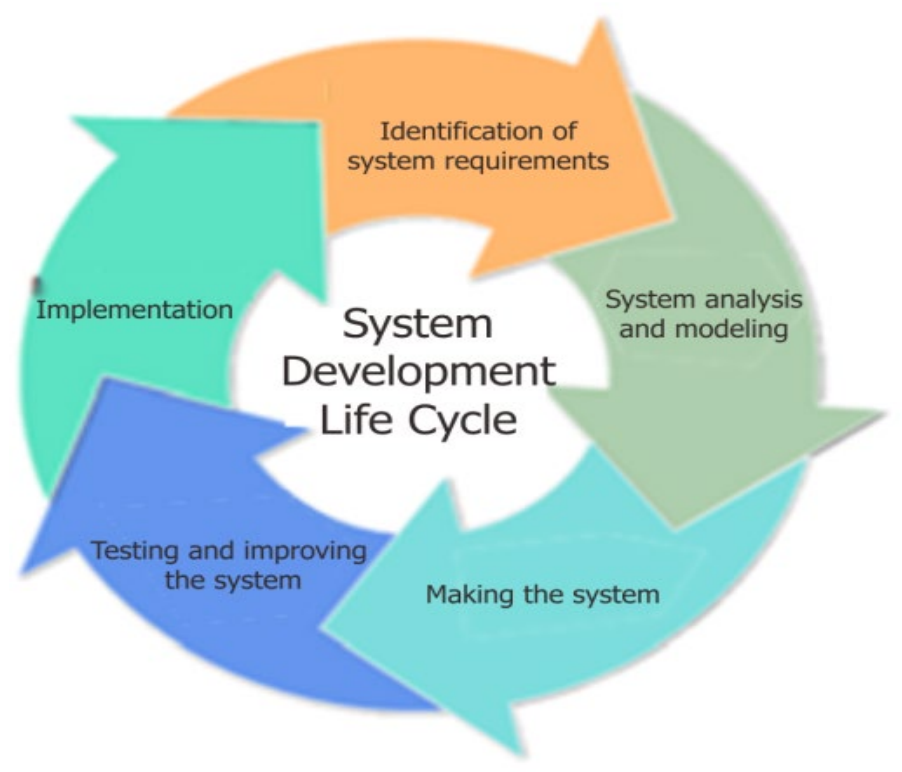

Figure 2: System Development Life Cycle Paradigm

The identification stage of system requirements begins with the preparation of research instruments in the form of interview guides and supporting tools such as tape recording, digital cameras, camcorders (video recording), transportation tools and supporting software. Furthermore, data collection is carried out directly or indirectly. Directly in the form of surveys to research locations to inventory the data needed and interviews with related parties, including: university leaders (rector, deans, heads of study programs), heads of support units, quality assurance units at the university level, faculties and study programs. Research data obtained at this stage is in the form of documentation and information about the quality management system in higher education a survey will be conducted at UKI Paulus.

The system analysis and modeling stage is carried out by analyzing and modeling the system with a flow map to determine the functions or activities that will be implemented in the system. Flow map systems are made in the form of context diagrams, data flow diagrams, entity relationship diagrams, relationships between files, file 
structures, program structures, menu structures, input formats and output formats. System analysis and modeling is carried out based on UML (Unified Modeling Language).

In the system development stage, the process of making the UKI Paulus Internal Quality Audit Information System Database system software is complete by using the UML technique, namely the selection of program packages that are suitable analysis for building the system.

The testing and repair phase of the system was carried out by testing the Internal Audit Quality Audit Information System Database for UKI Paulus based on the technology used. Tests were carried out on UKI Paulus computer devices and intranet networks. Testing was carried out on the Internal Academic Quality Audit activities at the UKI Paulus Electrical Engineering Study Program for the 2017/2018 academic year.

The implementation stage, by involving the Academic Quality Assurance Agency at UKI Paulus to implement the system in the implementation of the Internal Academic Quality Audit at UKI Paulus.

\section{RESULTS AND DISCUSSIONS}

Database The information system built is a system that uses computers as the main processing device. Humans act as regulator, operator, and main controller of these devices. The way the information system works is a substitute for the old system. Performing audits manually is replaced by the use of a computerized system. The authorized parties to access this information system are Administrators, Users (Auditor or Auditor) and Leaders. Administrators have a function for all system permissions which functions in entering new data, changing data and managing data system requirements. Input data in the system are: (1) User data; (2) Standard Data; (3) Unit Profile Data. Auditi users have access rights that function to input data on the AMAI assessment instrument. all system permissions. Lead users have access rights to view reports in the form of quality maps and graphs per component.

The login page is the page that first appears when the user accesses this system and the user is required to choose a login as according to their access rights and fill in the username and password to enter the main page (dashboard) in accordance with the user's access rights and if the username and password are entered incorrectly, the system will display a failed login message.

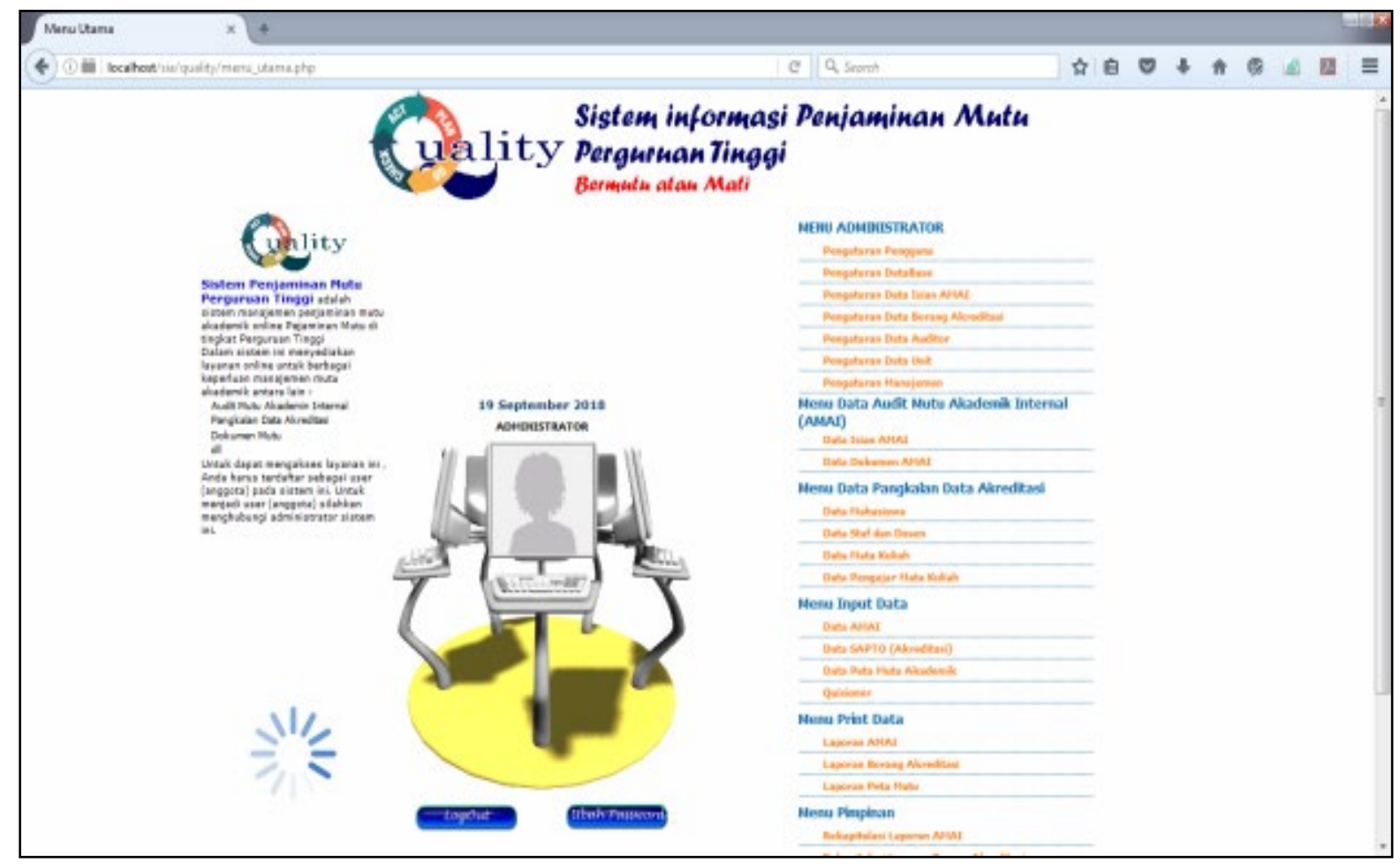

Figure 3: Administrator menu 


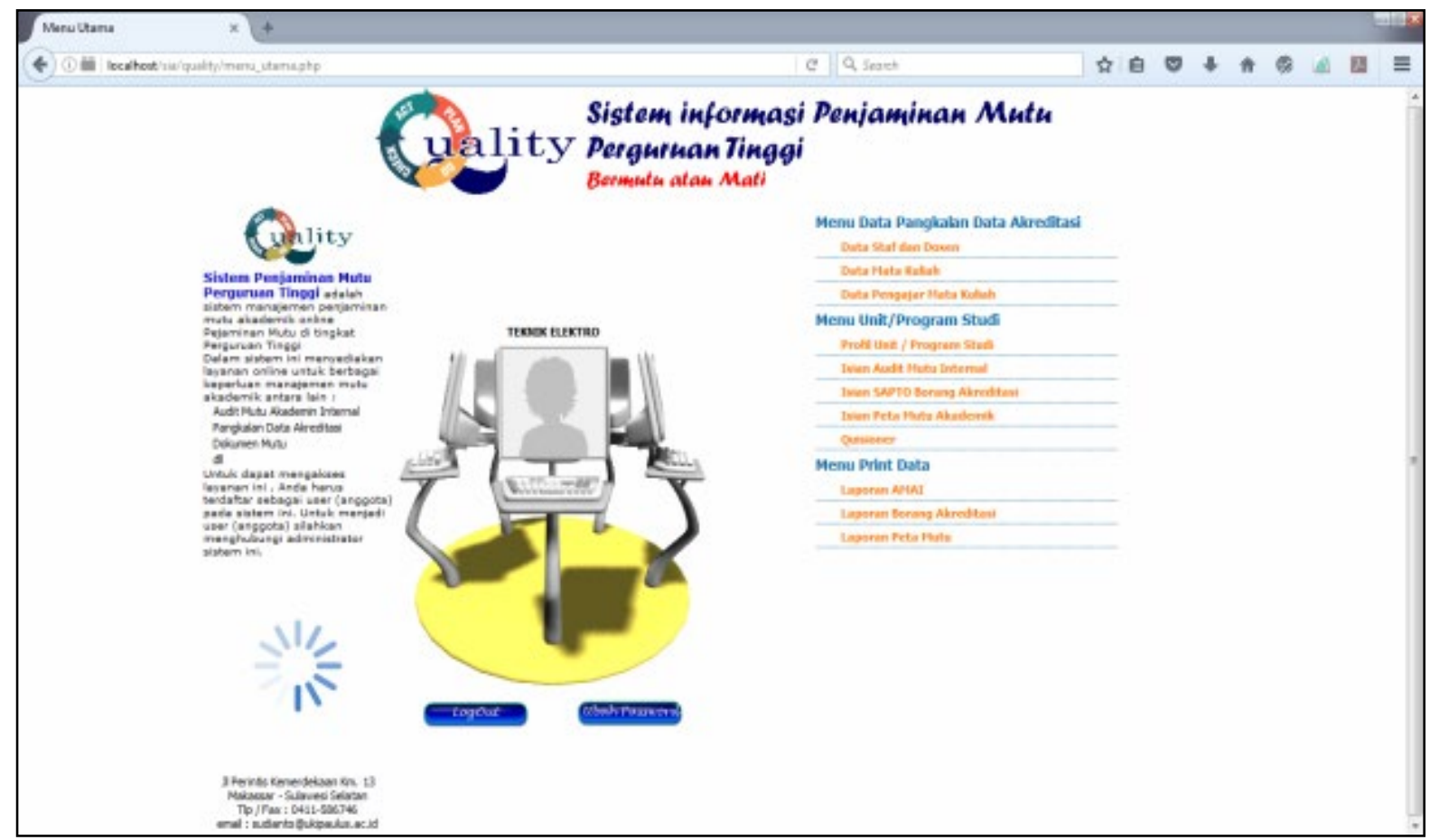

Figure 4: Auditi menu

The AMAI standard data page is a page for managing all standards that can be used at AMAI based on the BANPT study program accreditation form standards. Standard data has a relationship with perspective data, so each standards have a perspective. To add or change the AMAI standard, the administrator can select the standard menu list, components and aspect serial number and then click the save button.

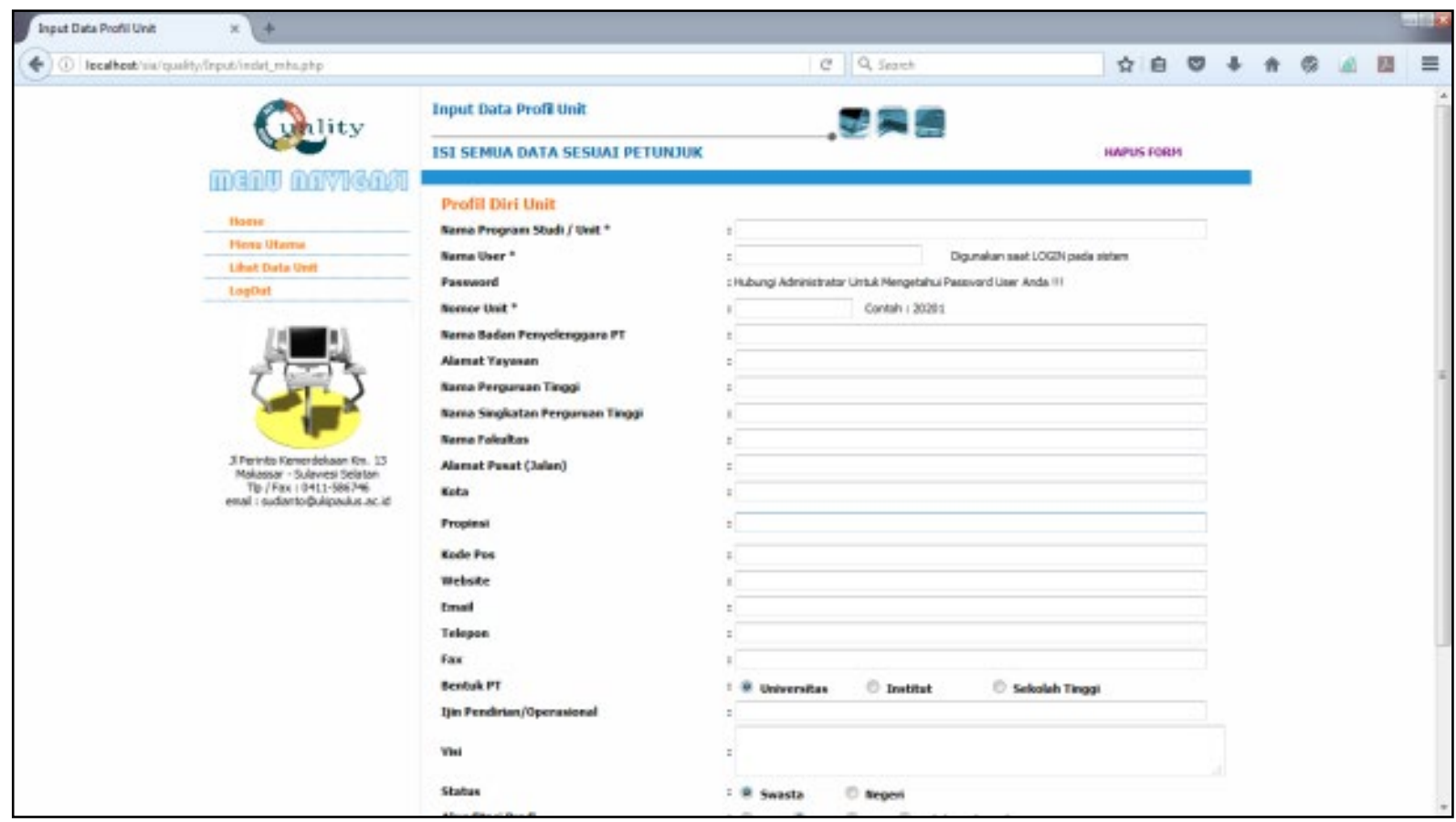

Figure 5: Unit self-profile menu 
Higher Education Internal Academic Quality Audit Information System

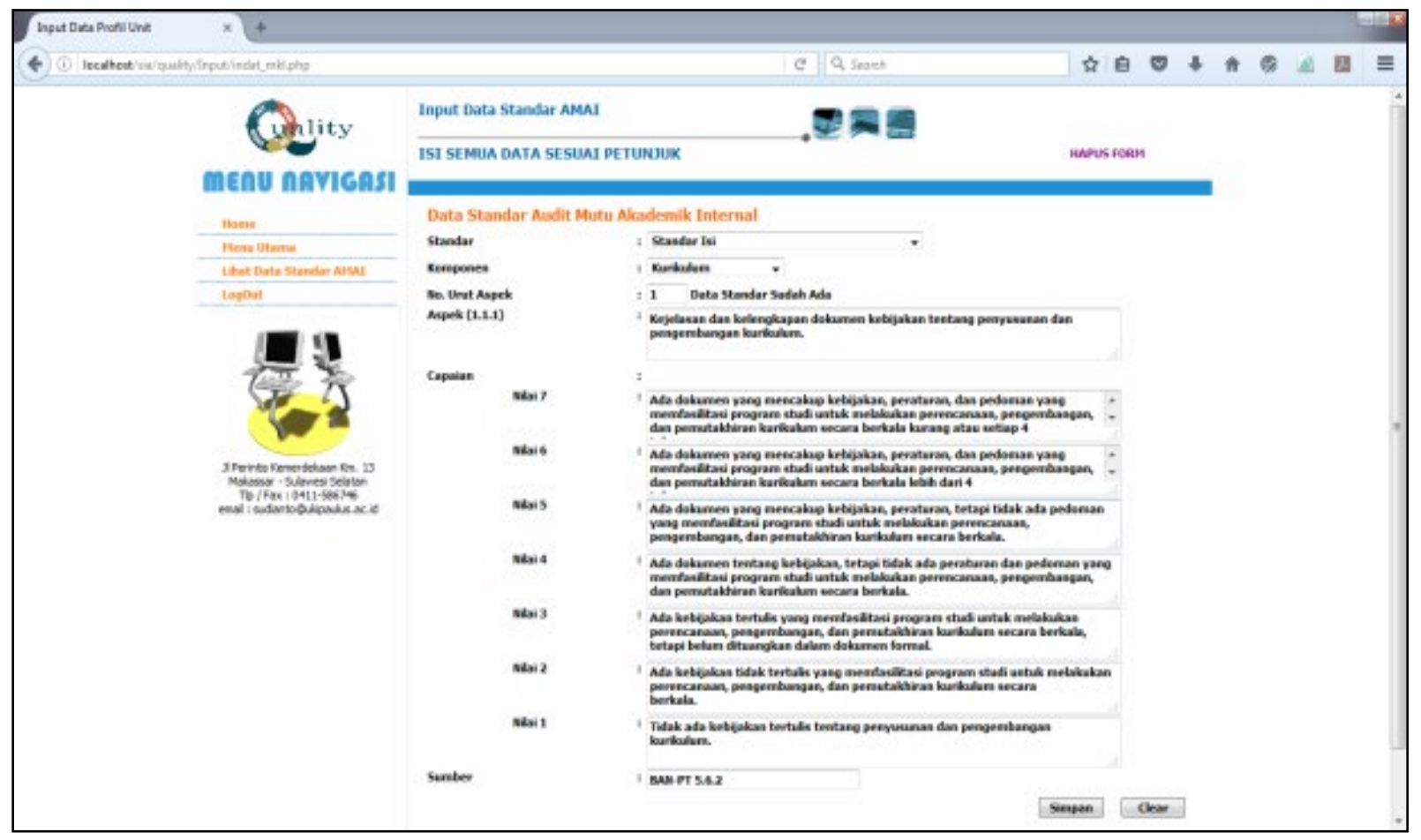

Figure 6: Internal academic quality audit standard data menu

The AMAI assessment instrument page is a page to fill in the data for the AMAI assessment instrument to be used at UKI Paulus. To add data to the AMAI instrument entry, the auditee selects a menu list for the academic year, standards, components, serial number of aspects and selects achievements according to the conditions of the unit or study program. On the analysis per indicator page, the auditee fills in the textfild of the condition of the unit / study program, root causes / supports, targets, improvement plans and financing plans / scenarios.

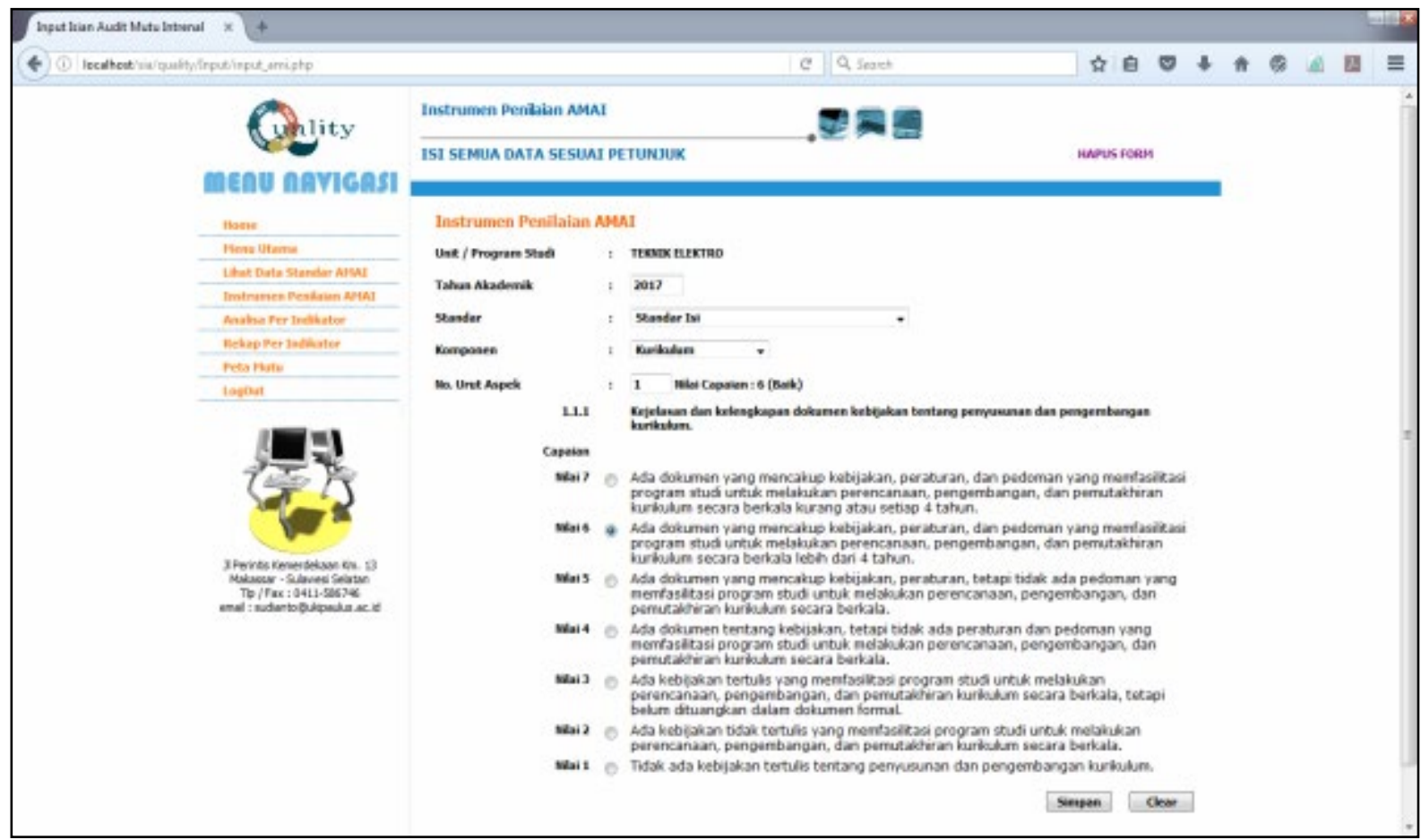

Figure 7: AMAI data entry menu 
Lande Sudianto, and Petrus Simon

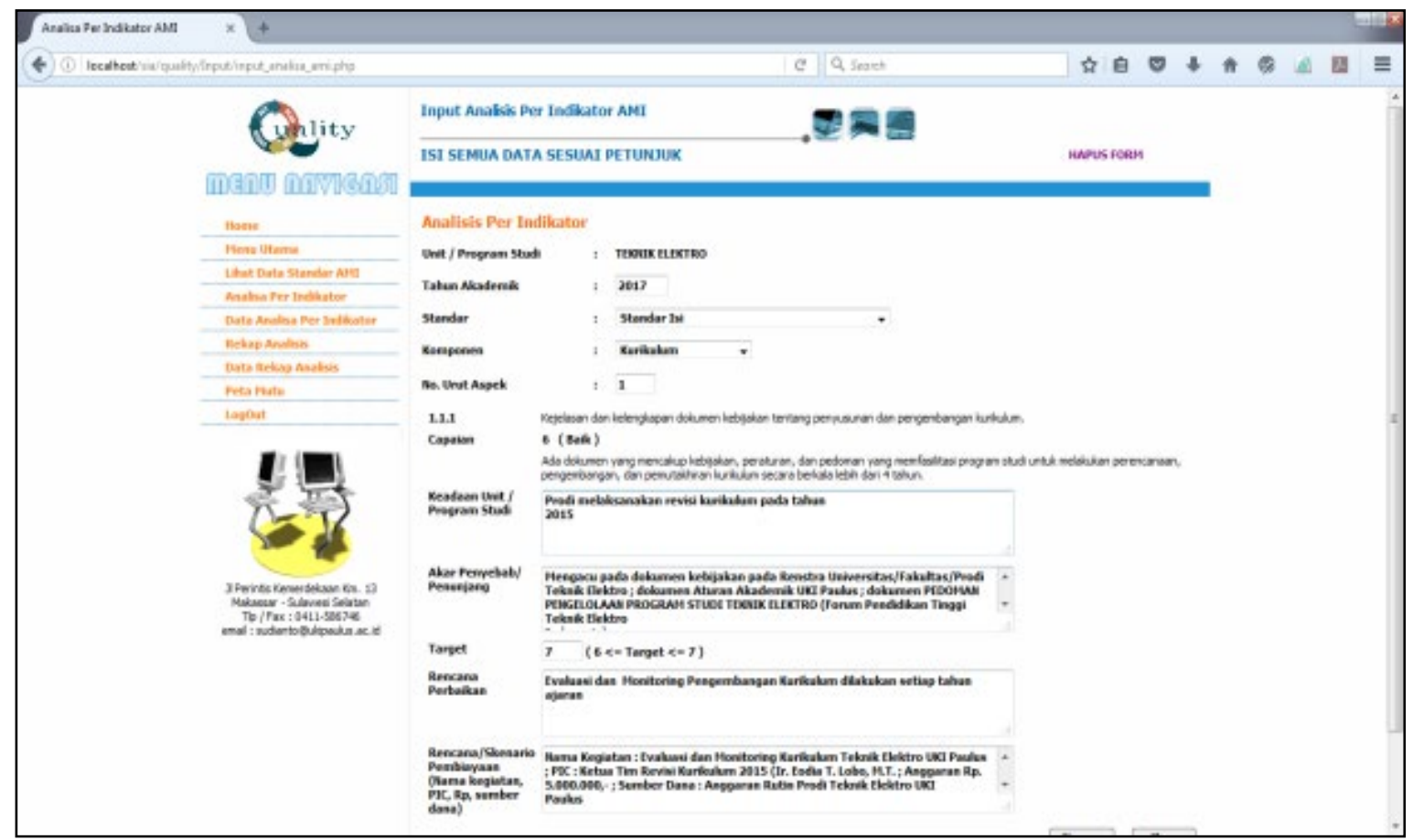

Figure 8: Analysis fields per indicator

Testing is done in the evaluation year / academic year 2018/2019. The results of testing with the whitebox and blackbox testing methods, obtained that the system is running according to the flow algorithm and the desired data structure and each. Table 1 shows the results of system testing. Based on Table 1, it can be concluded that all functional aspects of AMAI system assessment instrument to be used at UKI Paulus have been functioning properly and in accordance with the system design.

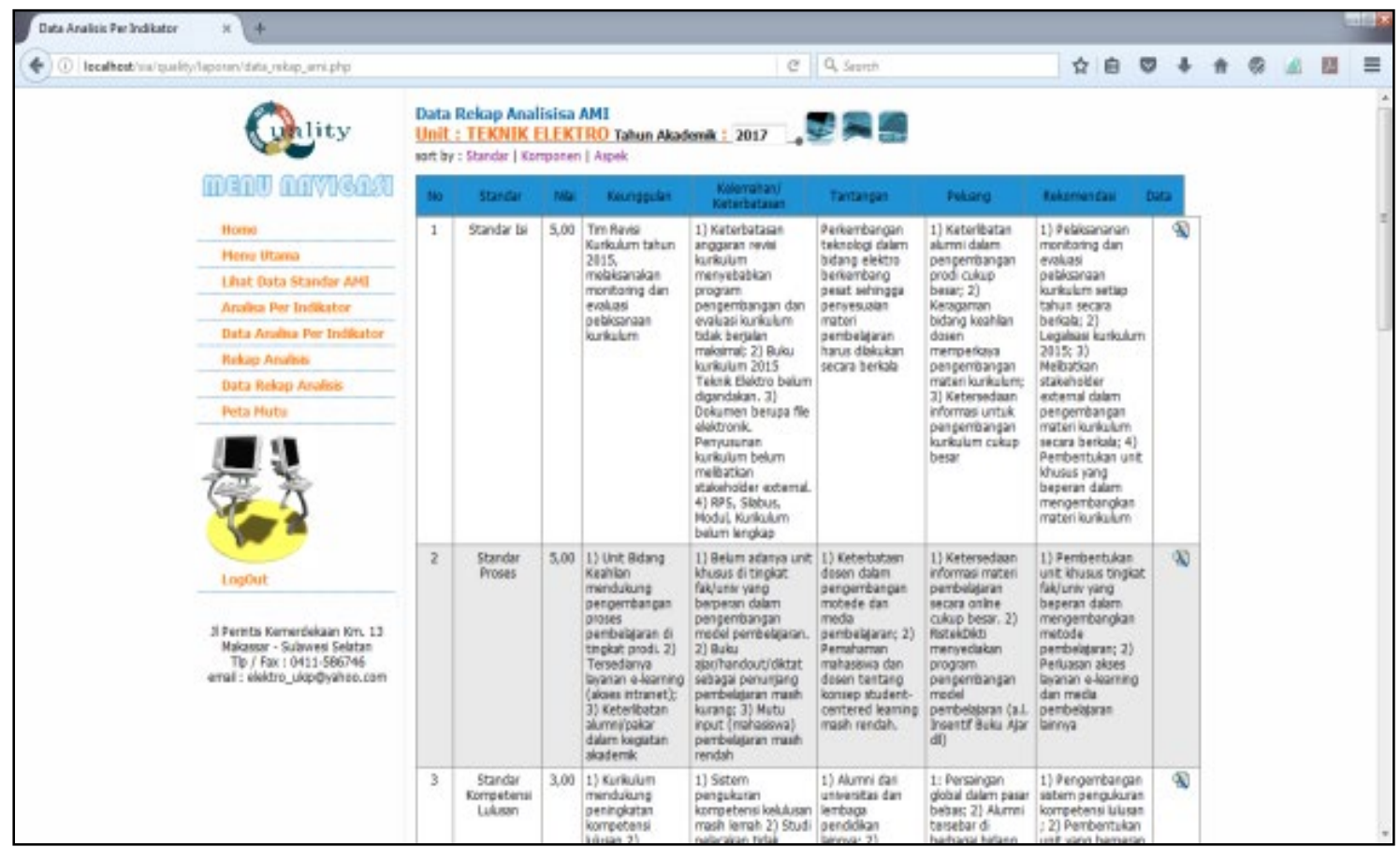

Figure 9: AMAI recap and report page 
Higher Education Internal Academic Quality Audit Information System

Table 1: System test results

\begin{tabular}{|c|c|c|c|}
\hline Function & Desired Results & Testing & Test result \\
\hline \multirow[t]{2}{*}{ Login } & \multirow[t]{2}{*}{$\begin{array}{l}\text { Each user (user) must fill in } \\
\text { the form username and } \\
\text { password correctly }\end{array}$} & $\begin{array}{c}\text { Fill in the correct } \\
\text { username and } \\
\text { password }\end{array}$ & Users can enter the main menu page \\
\hline & & $\begin{array}{l}\text { Fill in the wrong } \\
\text { username and / or } \\
\text { password }\end{array}$ & $\begin{array}{c}\text { The message "Fill in your User Name and } \\
\text { Password". Users cannot enter the main } \\
\text { menu page }\end{array}$ \\
\hline \multirow{2}{*}{$\begin{array}{l}\text { Fill in form } \\
\text { data }\end{array}$} & \multirow{2}{*}{$\begin{array}{l}\text { Fill in data forms and } \\
\text { verified and saved to the } \\
\text { database by the system }\end{array}$} & Fill in complete data & Data is stored in a database \\
\hline & & $\begin{array}{c}\text { Fill in incomplete data } \\
\text { or } \\
\text { Fill in the same data }\end{array}$ & $\begin{array}{l}\text { Data is not stored in the database, there } \\
\text { is a message display "data incomplete" or } \\
\text { "data already registered" }\end{array}$ \\
\hline $\begin{array}{l}\text { Changing } \\
\text { data }\end{array}$ & $\begin{array}{l}\text { Data changes according to } \\
\text { the code of each data }\end{array}$ & $\begin{array}{l}\text { Fill in or click the data } \\
\text { code of the form to be } \\
\text { changed }\end{array}$ & Form data changes in the database \\
\hline Wipe data & $\begin{array}{l}\text { Data is deleted according to } \\
\text { the code of each data }\end{array}$ & $\begin{array}{l}\text { Fill in or click the form } \\
\text { data code to delete }\end{array}$ & Data forms are deleted in the databas \\
\hline
\end{tabular}

Testing the level of user accessibility by measuring the level of user satisfaction with the system built. The test is performed by the administrator, dean, head of study program, faculty, administrative staff, and students involved in the process of accreditation. Responden provides an assessment of the 5 questions given, namely:

1) Display of AMAI system assessment instrument UKI Paulus.

2) Complete menu / form on the AMAI system assessment instrument UKI Paulus

3) Speed of response and access to the AMAI system assessment instrument UKI Paulus.

4) The accuracy of the data displayed in the AMAI system assessment instrument UKI Paulus.

Each question was rated using a scale of 5 (1 / No; 2 / Poor; 3 / Enough; 4 / Good; 5 / Very Good). From 40 respondents, the measurement results obtained from the user's accessibility level obtained by $96.75 \%$ for the scale (Good - Very Good)

\section{CONCLUSIONS AND RECOMMENDATIONS}

Planning and implementation of the internal academic quality audit information system database at the Paul Makassar Christian University of Indonesia is good enough and comprehensive by involving related elements proportionally. The AMAI information system database provides academic quality audit information more quickly and efficiently so as to simplify the process and documentation of the quality assurance system in higher education.

\section{SOURCES OF FUNDING}

This research received no specific grant from any funding agency in the public, commercial, or not-for-profit sectors.

\section{CONFLICT OF INTEREST}

The author have declared that no competing interests exist.

\section{ACKNOWLEDGMENT}

Our deepest gratitude to: (1) Directorate of Research and Community Service, Directorate General of Research and Development Strengthening, Indonesian Ministry of Research, Technology and Higher Education for funding this research through the 2018 Higher Education Leading Applied Research scheme; (2) UKI leaders Paulus for their 
support in carrying out this research; (3) Leaders and staff of UKI Paulus Quality Assurance Agency for their participation in providing data in this study; (4) Respondents who have been willing to provide the necessary information in this study (5) UKI Paulus Electrical Engineering IT Team who has helped develop this system.

\section{REFERENCES}

[1] Barclay, K., Savage, J., 2004. Object-Oriented Design with UML and Java: United States of America: Elseiver; 2004.

[2] Buku Panduan Pelaksanaan Sistem Penjaminan Mutu Perguruan Tinggi (SPM-PT) Bidang Akademik; Dirjen Dikti; 2006.

[3] Buku Panduan Sistem Penjaminan Mutu Perguruan Tinggi (SPM-PT: DirjenDikti; 2010.

[4] C. Laudon, Kenneth, P. Laudon, Jane. Management Information Systems:Managing The Digital Firm. Eleventh Edition.New Jersey, United States of America: Pearson Prentice Hall; 2010.

[5] Dennis, Alan, Wixom, Haley Barbara,Tegarden, David., Systems Analysis and Design with UML Version 2.0 : An Object-Oriented Approach.Second Edition. United States of America: John Wiley \& Sons, Inc.; 2005.

[6] El-Bakry, Hazem M., Proceeding of The 8th WSEAS International Conference on Education and Aducational Technology: Design of Quality Assurance Management System for E-Universities; 2010

[7] Andi G. Booch, I. Jacobson, J. Rumbaugh, “Object Oriented Analysis and Design with Aplications”, Third Edition, Pearson Educatio,; 2007.

[8] Haag, Stephen; \& Cummings, Meave,. Information Systems Essentials. Second Edition. New York: McGraw-Hill; 2008.

[9] Hoyle, David., ISO 9000 Quality System Handbook. Fourth Edition. United States of America: Elsever; 2001.

[10] Hoyle, David., Quality Management Essentials. United States of America: Elsever; 2007.

[11] McLeod, Jr. Raymond, P. Schell, George,. Management Information Systems. Tenth Edition.New Jersey, United States of America: Pearson Prentice Hall; 2007.

[12] Mishra, Dr, Sanjaya,. Quality Assurance In Higher Education An Introduction India: National Printing Press; 2007

[13] Munawar. Pemodelan Visual dengan UML. EdisiPertama. Yogyakarta:PenerbitGrahallmu; 2005.

[14] O’Brien, A. James. PengantarSistemInformasiPerspektifBisnisdanManajerial. Jakarta: PenerbitSalembaEmpat; 2006.

[15] Permendiknas No.63 Tahun 2009 TentangSistemPenjaminanMutuPendidikan PP No.19 Tahun 2005 Tentang Standar Nasional Pendidikan (SNP) PP No.7 Tahun 2007 Tentang Organisasidan Tata Kerja Lembaga Penjaminan Mutu Pendidikan; 2005

[16] Pressman, Roger S. 2001.Software Engineering: A Practitioner's Approach. Fifth Edition. New York: McGrawHill; 2001

[17] R. Weber,"Information System Control and Audit", the University of Queenisland, Prentice Hall; 1999.

[18] Schlickman, Jay.. ISO 9001:2000 Quality Management System Design. London: Artech House; 2003

[19] Silberschatz, Abraham Korth, Henry F., S. Sudarshan,. Database System Concepts. Sixth Edition. NewYork: McGraw-Hill; 2011.

[20] Sudianto L, Simon P..Torajapedia (Ensiklopedia Virtual SeniUkiranToraja), Seminar Nasional Otomasi Industri dan Teknologi Informasi, Institut Teknologi Sepuluh Nopember (ITS), Surabaya; 2015

[21] Lande Sudianto, Petrus Simon. Application of Monitoring Database for Accreditation Instrument UKI PAULUS. IOP Conf. Series: Materials Science and Engineering 846 (2020) 012027: IOP Publishing 